\title{
COMPARISON OF STANDARD DIAGNOSTIC AND RADIOTHERAPY PLANNING PROTOCOLS IN LUNG CANCER TREATMENT ON PET/ CT SCANNER
}

\author{
PRIMERJAVA KLASIČNEGA DIAGNOSTIČNEGA IN RADIOTERAPEVTSKEGA PROTOKOLA V \\ RADIOTERAPIJI PRI RAKU PLJUČ NA PET/CT APARATU
}

\author{
Filip VLAJ ', Katja ŠKALIČ², Valerija ŽAGER MARCIUŠ ${ }^{1,3}$ \\ 1 University of Ljubljana, Faculty of Health Sciences, Department of Medical Imaging and Radiotherapy, Zdravstvena pot 5, \\ 1000 Ljubljana, Slovenia \\ 2 Institute of Oncology Ljubljana, Department of nuclear medicine, Zaloška ulica 2, 1000 Ljubljana \\ 3 Institute of Oncology Ljubljana, Department of teleradiotherapy, Zaloška ulica 2, 1000 Ljubljana \\ Corresponding author: valerija.zager@zf.uni-lj.si, vzager@onko-i.si
}

Received: 30.11 .2020

Accepted: 30.12 .2020

https://doi.org/10.47724/MIRTJ.2020.i02.a002

\begin{abstract}
Purpose: The purpose of the study was to compare the standard diagnostic protocol for computed tomography imaging with a radiotherapy imaging protocol for treatment planning needs in radiotherapy for lung cancer on a positron emission tomography (PET/CT) scanner at the Department of Nuclear Medicine in order to then be able to determine the differences between these two protocols and suggest improvements in dose optimisation for computed tomography imaging in a radiotherapy protocol.

Methods: In a retrospective study, data were collected with the SyngoVia program and statistically analysed according to the patient dose load in computed tomography imaging in standard PET /CT and radiotherapy protocols. The analysis included data of 56 patients for the period from 1 January 2017 to 1 December 2018. We compared data on patient dose load in computed tomography imaging in a standard protocol before and after introducing the improved sinogram-affirmed iterative reconstruction method (SAFIRE).
\end{abstract}

Results and discussion: Statistically significant differences in dose per patient $\left(p<10^{-3}\right)$ in computed tomography imaging in standard PET/CT and radiotherapy protocols on PET/CT scanner were found. Statistically significant differences were also established in computed tomography imaging in the standard PET/CT protocol before and after the introduction of the improved iterative reconstruction method $(p=0.001)$. Dose load on the lung in computed tomography imaging was $67.5 \%$ lower in the standard protocol with the iterative reconstruction in image space (IRIS) method than in the radiotherapy protocol. The introduction of the improved SAFIRE method additionally lowered the dose per patient by $34.2 \%$ compared to the IRIS method.

Conclusion: In the future, the improved iterative reconstruction method should be introduced for the reconstruction of computed tomography images for radiotherapy imaging protocol in lung cancer. The impact of the indirect reduction in the dose, which has an influence on the accuracy of the contouring of tumour target volumes for patient treatment planning, should be taken into account.

Key words: positron emission tomography with computed tomography, iterative reconstruction, dose optimization, lung cancer, radiation treatment planning

\section{IZVLEČEK}

Namen: Namen raziskave je bil primerjati klasični diagnostični protokol slikanja z računalniško tomografijo z radioterapevtskim protokolom slikanja za potrebe planiranja $v$ radioterapiji pri pljučnem raku na aparatu za pozitronsko emisijsko tomografijo (PET/CT) na oddelku za nuklearno medicino, ugotoviti razlike med njima in predlagati morebitne izboljšave pri optimizaciji doze prejete ob slikanju $z$ računalniško tomografijo pri radioterapevtskem protokolu.

Metode in materiali: $V$ retrospektivni raziskavi smo s programom SyngoVia pridobili in podatke $s$ statistično analizo primerjali, glede na dozno obremenitev bolnikov slikanih z računalniško tomografijo pri klasičnem PET/CT in radioterapevtskem protokolu. V analizi je bilo vključenih skupno 56 bolnikov $v$ obdobju od 1.1.2017 do 1.12.2018. Primerjali smo tudi podatke o dozni obremenitvi bolnikov z računalniško tomografijo pri klasičnem protokolu pred in po uvedbi izboljšane iterativne rekonstrukcijske metode SAFIRE.

Rezultati in razprava: Ugotovili smo, da pri slikanju $z$ računalniško tomografijo pri klasičnem PET/CT in radioterapevtskem protokolu obstajajo statistično značilne razlike $v$ dozi na bolnika $\left(p<10^{-3}\right)$ na PET/CT aparatu. Statistično značilne razlike smo ugotovili tudi pri slikanju $z$ računalniško tomografijo pri klasičnem protokolu pred in po izboljšavi iterativne rekonstrukcijske metode $(p=0,001)$. Dozna obremenitev pljuč z računalniško tomografskim slikanjem pri klasičnem protokolu z iterativno rekonstrukcijsko metodo IRIS je bila v primerjavi z radioterapevtskim protokolom nižja za $67,5 \%$. Uvedba izboljšane iterativne rekonstrukcijske metode SAFIRE je, v primerjavi s predhodno iterativno rekonstrukcijsko metodo IRIS, dozo na bolnika še dodatno znižala in sicer za $34,2 \%$.

Zaključek: V prihodnje je za rekonstrukcijo računalniško tomografskih slik, možna uvedba izboljšane iterativne rekonstrukcijske metode tudi za radioterapevtski protokol slikanja pri raku pljuč. Pri tem bo potrebno upoštevati vpliv posrednega zmanjšanja doze, ki vpliva na natančnost vrisovanja tarčnih volumnov pri izdelavi obsevalnega načrta za bolnika.

Ključne besede: pozitronska emisijska tomografija z računalniško tomografijo, iterativna rekonstrukcija, optimizacija doze, pljučni rak, planiranje obsevanja 


\section{INTRODUCTION}

Radiotherapy as a medical science is often the most appropriate treatment method (1) for some types of lung cancer. An important part of radiation treatment for lung cancer is the preparation of the patient for radiation on a computed tomography (CT) simulator at the Department of radiotherapy. Preparation for treatment planning can also be performed on a PET/CT scanner at the Department of nuclear medicine using positron emission tomography with computed tomography (PET/CT) with the standard diagnostic PET/CT scan first, followed by the imaging protocol for treatment planning in radiotherapy, i.e. radiotherapeutic protocol.

The fusion of both image series enables radiotherapists to accurately identify tumour target volumes and critical organs for treatment planning in radiotherapy $(2,3)$. The accuracy of the identification influences the facilitation of the optimal dose coverage of the target volume and the minimum dose for critical organs and healthy tissue, which consequently reduces the side effects of radiation (4).

$\mathrm{PET} / \mathrm{CT}$ is a hybrid imaging technique combining positron emission tomography and computed tomography. The fusion of images is obtained by combining both techniques. A PET image shows the distribution of a radiopharmaceutical, while a CT image shows morphology and anatomy. Increased metabolism, glycolysis, protein synthesis and DNA are characteristic of tumours. The most common radiopharmaceutical for PET imaging is [18]F-flourodeoxyglucose (18F-FDG). 18F-FDG is accumulated proportionally to the glucose metabolism, i.e., at the tumour location, modified lymph nodes and potential metastases. A standard PET/CT scan with 18F-FDG is performed one hour after the administration of a radiopharmaceutical. All nuclear medicine examinations show modifications on the cell level and are, therefore, used for the early detection of metabolic changes, the identification of disease, as an aid in radiation planning in radiotherapy and for monitoring the treatment outcome $(5,6)$.

Each radiation is planned. Anatomic and physiologic data of the area must be collected prior to the lung cancer irradiation on a CT simulator or PET/CT scanner. We obtain a detailed image of the radiopharmaceutical's distribution in the tissue of the imaged area with PET/CT imaging, which was proven more efficient than a separate imaging with a CT simulator or a PET scanner. The identification of target volumes on the images obtained with a PET/CT scanner enables a more accurate detection of tumour volumes than with a CT simulator alone since a PET image provides a clearer differentiation of healthy and cancerous tissue. A decrease in radiation volume contributes to a lower exposure of healthy tissue and thus, less side effects of radiation for a patient (6).

The computer eliminates different physical and electronic disturbances in computed tomography before reconstruction. Reconstruction of the CT image is conducted using different reconstruction algorithms (listed below) that consequently influence the received dose and output image quality (7). One of the analytical reconstruction algorithms is the filtered back projection (FBP). Analytical reconstruction algorithms are simple mathematical methods, where modifications of output images occur due to false presumptions on geometric beam properties and matrix geometry. Analytical algorithms presuppose that the source of X-ray photons and each detector cell are infinitely small and that each voxel has no size or form (8). In the iterative method (statistical and modelbased), data do not change and adapt in order to comply with the analytical reconstruction models, but the circular process of obtaining, comparing and updating data is introduced into the reconstruction process, which leads to an improved diagnostic accuracy of output CT images (8). The adaptive statistical iterative reconstruction (ASIR) method is a circular system where artificial data is synthesised based on the estimation of obtained data. These raw data are then compared to realistic data that were obtained in the imaging process. The difference between the two sets of data is used again in the first step, where they are again compared to realistic data. This process is repeated until the difference between both sets of data is at an acceptable interval (8). The modelbased iterative reconstruction (MBIR) method proved to be successful in improving image quality due to reduced noise and artifacts. In addition to the components of the adaptive statistical iterative method, the reconstruction algorithm adds models. These models take into account the polychromatic feature of the X-ray beam and geometric features of the detector, and thus accelerate the reconstruction process. Studies have shown that the lung dose load decreased by $79 \%$ to $98 \%$ when iterative reconstruction was applied (8).

In computed tomography, the dose is applied with the computed tomography dose index (CTDI) and dose length product (DLP). CTDIvol defines the intensity of radiation used to perform a particular CT examination. The CTDIvol is settled for a given CT unit and a set of acquisition parameters, so it does not depend on patient size or scan length. DLP is the product of CTDI and the total length of the imaging area. The methods of calculating the received dose in CT imaging are precisely described in the relevant literature (9).

The purpose of this study was to compare the standard PET/ CT imaging protocol with the radiotherapeutic protocol for lung cancer on a PET/CT scanner, to determine the differences between these two protocols and to propose possible improvements in the dose optimisation for CT imaging in the radiotherapy protocol.

\section{METHODS}

Scientific literature from the library of the Faculty of Health Sciences and online sources were used. A retrospective study compared data from 56 patients that underwent PET/ CT imaging in standard PET/CT and radiotherapy protocols for radiotherapy planning for lung cancer from 1st January 2017 to 1st December 2018 on PET/CT scanner. Data were compared on patient dose in CT imaging in the standard PET/ CT protocol before and after implementation of the improved SAFIRE method for dose optimisation (which has been applied since July 2018) and the relevant statistical analyses was conducted. Data were collected using the SyngoVia software, which provides reviewing and processing tools for evaluating all radiology images, including images from hybrid scanners (PET/CT, SPECT/CT).

Both scans of the patient were performed on the same day, one after the other, at the Department of Nuclear Medicine (10). The patient was administered a radiopharmaceutical (18F-FDG), followed by the PET/CT standard imaging using the standard PET/CT protocol with an aim to determine the 
prevalence of the disease. PET/CT imaging was followed by the radiotherapy protocol for radiation treatment planning. Imaging parameters of the protocols differ in terms of the selected voltage $(\mathrm{kV})$, current (mAs) and imaging area size. The patient was prepared for the second part of the imaging according to the preparation protocol for the radiation of lung cancer in radiotherapy (use of flat examination table, selection of appropriate fixation devices, and external laser system for the placement of the patient in the initial isocentre).

Microsoft Excel 2016 and IBM SPSS Statistics 24 were used for the analysis and evaluation of data. Statistically significant changes were $p$-valued at $p \leq 0.05$ (risk level 5\%). The ShapiroWilk test was used to determine whether our numerical dependent variables were distributed normally. Based on the result, we then applied parametric or non-parametric tests. The Mann-Whitney $U$ test was used for independent samples to determine differences in the CT dose for 46 patients. We determined whether differences in pivot values between sample groups were statistically significant. To determine the differences in the CT lung dose for 46 patients between the PET/CT standard and radiotherapy protocol, we made a preliminary calculation of the adjustment factor that we used to equalise the length of the imaging area of both protocols (11). The length of the imaging area in the standard protocol is longer as it includes a field from the skull base to the proximal third of the femur. Data on DLP in the PET/CT standard protocol were divided by the aforementioned factor. We thus obtained a DLP that describes the received dose in the area of the same size as the imaging area in the radiotherapy protocol, where the lung is scanned from the thyroid cartilage to the middle of the kidneys (to the lower edge of the ribs). The adjustment factor was calculated based on the table containing DLP values (Figure 1) that were measured on a phantom, and amounts to 3.35. The calculation took into account possible deviations in the imaging area size of each imaging.
To determine differences in the sample of 46 patients before and a sample of 10 patients after the implementation of the improved SAFIRE method, we applied the Wilcoxon test for dependent samples, based on the abnormal distribution of one of the samples.

\section{RESULTS}

The CT dose for 46 patients using the radiotherapy protocol without the iterative reconstruction method was compared to the CT dose obtained using the standard PET/CT protocol. Also, the CT dose of the CT scan using the IRIS optimisation dose method and thus the SAFIRE optimisation method were compared. Moreover, to equalise the length image area solely on the thorax, we divided the DLP values of the standard protocol by the calculated adjustment factor to compare the CT dose of the radiotherapy and standard PET/CT protocols. For comparison purposes, the field in both protocols was equalised. The standard PET/CT imaging area was divided by the calculated adjustment factor of 3.35 to arrive at the size of the radiotherapy area protocol.

\section{Patient dose load in CT imaging in standard $\mathrm{PET} / \mathrm{CT}$ and radiotherapy protocols}

We compared data for 46 patients (Figure 2) who underwent CT imaging using the standard and radiotherapy PET/ CT protocols. The reconstruction of the CT images of the radiotherapy protocol was conducted without using the iterative reconstruction method, whilst the reconstruction of the standard protocol used the iterative reconstruction method. Women and men accounted for $26.09 \%$ and $73.91 \%$ of the sample, respectively.

Samples were not normally distributed (radiotherapy protocol $(p=0.030)$, standard protocol $(p=0.044)$. Using a

\section{Representative CTDI ${ }_{\text {vol }}$ DLP, and ED Values for Normal-sized Adults Undergoing Specified Routine CT Examinations}

\begin{tabular}{|c|c|c|c|c|c|}
\hline \multirow[b]{2}{*}{ Body Region* } & \multicolumn{2}{|c|}{$\mathrm{CTDI}_{\mathrm{vol}}(\mathrm{mGy})^{\dagger}$} & \multicolumn{2}{|c|}{$\mathrm{DLP}(\mathrm{mGy})^{\dagger}$} & \multirow[b]{2}{*}{$\mathrm{ED}(\mathrm{mSv})^{\ddagger}$} \\
\hline & In 16-cm Phantom & In 32-cm Phantom & In 16-cm Phantom & In 32-cm Phantom & \\
\hline Head (15 cm) & 60 & (30) & 900 & $(450)$ & 2.2 \\
\hline Chest (30 cm) & (30) & 15 & (900) & 450 & 9.0 \\
\hline Abdomen $(25 \mathrm{~cm})$ & (40) & 20 & (1000) & 500 & 8.0 \\
\hline Pelvis (25 cm) & (40) & 20 & (1000) & 500 & 7.0 \\
\hline Brain (perfusion) & 440 & (220) & 2400 & (1200) & 5.8 \\
\hline
\end{tabular}

Note.-Most manufacturers use a $16-\mathrm{cm}$ phantom to calculate the CTDI for head examinations and a $32-\mathrm{cm}$ phantom to calculate the CTDI for all body examinations (including the neck) (19).

* Numbers in parentheses are scan lengths.

${ }^{\dagger}$ Numbers in parentheses are not commonly encountered in clinical practice.

‡ Computed with ICRP publication 103 tissue-weighting factors (7). 
non-parametric test for independent samples, we did not identify statistically significant differences in the patient dose load in CT imaging in the radiotherapy and standard PET/CT protocols $(p=0.138)$.

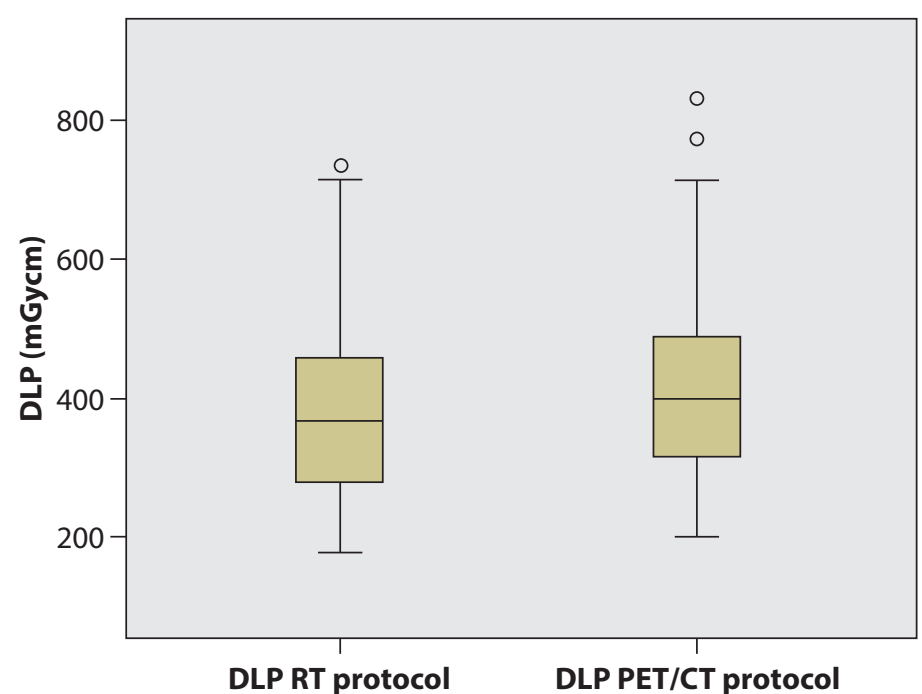

Figure 2: Comparison of the DLP of the radiotherapy (RT) and standard PET/CT protocols

\section{Lung dose load in $\mathrm{CT}$ imaging in the radiotherapy protocol without the iterative reconstruction method and in the standard PET/CT protocol with the IRIS method}

The sample included 46 patients. The graph (Figure 3) was based on the DLP data. To equalise the field in both protocols, we divided the size of the field in the standard PET/CT protocol by the calculated adjustment factor of 3.35.

Samples were not normally distributed (radiotherapy protocol $(p=0.030)$, standard PET/CT protocol $(p=0.044))$. Using a nonparametric Wilcoxon signed rank test for dependent samples,

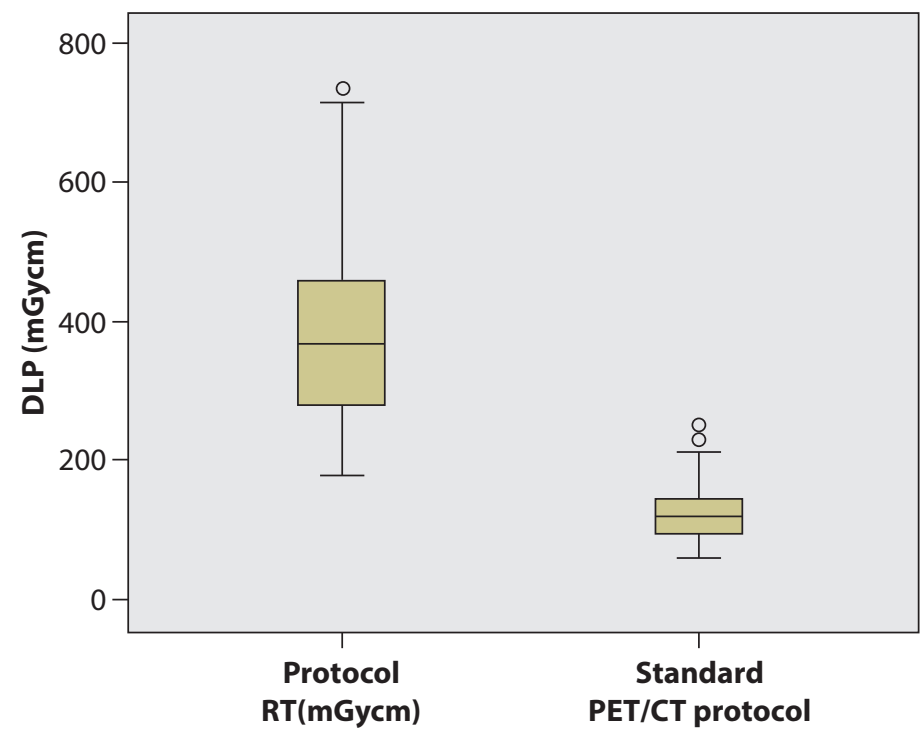

Figure 3: Comparison of the DLP on the lung in the radiotherapy (RT) and standard PET/CT protocols we identified statistically significant differences in the CT dose on lungs for the mentioned protocols $\left(p<10^{-3}\right)$.

\section{Effect on the dose obtained before and after implementation of the improved iterative reconstruction method in the standard PET/CT protocol}

The sample included 46 patients (Figure 4) before the improved iterative reconstruction (using IRIS) and 10 patients after the improved SAFIRE method. Data of the improved iterative reconstruction method (SAFIRE) are normally distributed $(p=0.266)$, while the data for which the iterative reconstructed method was used were not normally distributed $(p=0.044)$.

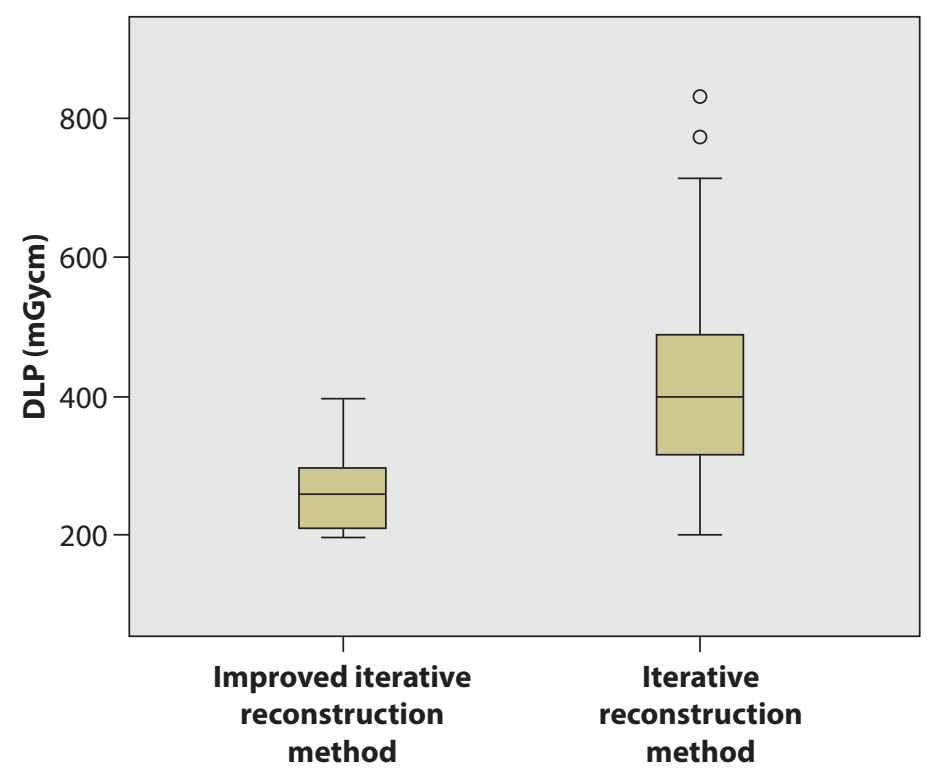

Figure 4: Comparison of the DLP in the standard PET/CT protocol before and after the improved iterative reconstruction method

The Mann-Whitney $U$ test for independent samples showed statistically significant differences in the dose in the standard $\mathrm{PET} / \mathrm{CT}$ protocol before and after the implementation of the improved iterative reconstruction method $(p=0.001)$.

\section{DISCUSSION}

The aim of our research was to determine how the implementation and improvement of an iterative reconstruction method influences the patient dose during $\mathrm{CT}$ imaging. We compared the differences in the $\mathrm{CT}$ dose in standard PET/CT protocol and radiotherapy protocols in lung cancer, performed on a PET/CT scanner. PET/CT scans using standard and radiotherapy protocols showed no statistically significant difference in the dose received by a patient. However, the protocols have imaging areas of different sizes. As a result, the streaming adjustment must also be implemented. The standard PET/CT scan is at least one time longer than a scan in the radiotherapy protocol.

In order to compare the DLP of the protocols in question, we used data from literature to calculate an adjustment factor (11) that we used to equalise the length of the imaging area of both protocols. The results indicated that the CT dose 
differed between the two protocols. The median $C T$ value of the radiotherapy protocol was 367 , while the median value of the standard PET/CT protocol was 119.25. The dose received by the patient in the lung area in the standard PET/CT protocol using the IRIS method was $67.5 \%$ lower than the dose in the radiotherapy protocol without the use of the IRIS method. There are several potential reasons for deviations in the final estimate of the received dose. The first that should be mentioned is the factor of 3.35 obtained based on a comparison of ratios stated in the literature, which had to be adjusted to our imaging area (11). The size of the imaging area also depends on the patient's anatomy and the length of the imaging area set by the radiographer. The results from a subsequent study were obtained from a phantom and patients. Those results proved that the dose decreases by between $32 \%$ and $65 \%$ when adaptive iterative reconstruction is used. This coincides with our results (12). We then compared the differences in DLP in the standard $\mathrm{PET} / \mathrm{CT}$ protocol before and after the implementation of the improved iterative reconstruction method. There were 46 patients in the sample prior to introducing the improved iterative reconstruction method, and 10 patients following the improvement made in the scope of our research. Using statistical analysis, we determined that the median value prior to the improvement of the IRIS method was 399.50, while the median value following the introduction of the improved SAFIRE method was 263 , meaning that the dose was reduced by $34.2 \%$ following the introduction of an advanced iterative reconstruction method.

We were limited in terms of the number of patients in the sample following the introduction of the improved SAFIRE method, as we began using the reconstruction method at our institution at the beginning of July 2018, which affected the accuracy of the statistical analysis. The SAFIRE method, which is used in the reconstruction of CT images in the standard PET/ CT protocol, also effectively reduced the patient dose load. It thus makes sense to ask the question whether the use of this type of reconstruction method could also reduce the patient dose load in CT imaging in the radiotherapy protocol while maintaining an image quality that is suitable for identifying target tumour volumes. Current guidelines indicate that $a$ low-dose CT is not in itself appropriate for radiation treatment planning. In this case, a high-dose CT of a shorter target area for planning following a low-dose CT of a longer imaging area is required to reduce the dose load (13).

We can conclude that it would make sense to introduce the SAFIRE method in the radiotherapy PET/CT protocol for reconstructing $C T$ images. However, when introducing the iterative reconstruction method with an aim of reducing the patient CT dose, it would be necessary to perform an additional analysis of the impact of the indirect reduction in dosage on the precision of the contouring of tumour target volumes and critical organs. It was proven that the resolution in low-dose CT using an adaptive statistical iterative method was poorer than the resolution in low-dose CT using a model-based iterative method. The model-based iterative reconstruction method, which is already used in practice, effectively reduces the dose and image noise, improves spatial and contrast resolution, and eliminates image artefacts $(8,12)$.

\section{CONCLUSION}

In our study we compared the differences in $\mathrm{CT}$ dose in standard PET/CT and radiotherapy protocols in lung cancer performed on a PET/CT scanner. In the standard protocol, an advanced iterative reconstruction method was used. That method facilitates lower patient dose loads. We determined that the CT dose is $67.5 \%$ lower in the standard PET/CT protocol than in the radiotherapy protocol when the size of the imaging field is the same. Imprecision in the definition of the adjustment factor used to equalise the imaging field must be taken into account. It would make sense in the future to calculate the adjustment factor based on a phantom as this would lead to more precise input data for analysis.

When comparing the effect on the dose obtained before and after the implementation of the improved iterative reconstruction method in the standard PET/CT protocol, we determined that the patient dose load was reduced by $34.2 \%$ using the improved iterative reconstruction method. The sample of patients following the implementation of the improved iterative reconstruction method was small during the course of our study, as that method was introduced in July 2018. In the future, the study should be repeated with a larger sample.

\section{REFERENCES}

1. Strojan P. Teleradioterapija. In: Strojan P, Hočevar $M$, editors. Onkologija, učbenik za študente medicine. 1st ed. Ljubljana; Onkološki inštitut Ljubljana; 2018. p. 226-47. Available from: https://www.onko-i.si/ucbenik_ onkologija/.

2. Khan FM, Gerbi BJ. Treatment planning in radiation oncology. 3rd ed. Philadelphia: Lippincott Williams \& Wilkins; 2012.

3. National Cancer Institute. Radiation Therapy to Treat Cancer; 2018. Available from https://www.cancer.gov/ about-cancer/treatment/types/radiation-therapy.

4. Peters AM. PET imaging in lung cancer. In: Peters AM, editor. Nuclear Medicine in Radiological Diagnosis. United Kingdom: Taylor \& Francis Group; 2003; 617-31.

5. Kapoor V, McCook BM, Torok FS. (2004). An Introduction to PET-CT Imaging. Radiographic. 2004; 24(2): 523-43. doi: 10.1148/rg.242025724. Available from https://pubs. rsna.org/doi/full/10.1148/rg.242025724.

6. Ruysscher DD, Nestle U, Jeraj R, MacManus M. PET scans in radiotherapy planning of lung cancer. Lung cancer. 2012; 75(2):141-5.

7. Goldman LW. Principles of CT and CT Technology. J Nucl Med Technol. 2007; 35: 115-28. doi: 10.2967/ jnmt.107.042978. Available from:http://tech.snmjournals. org/content/35/3/115.full.pdf+html.

8. Liu L. Model-based Iterative Reconstruction: A Promising Algorithm for Today's Computed Tomography Imaging. J Med Imag Radiat Sciences. 2014; 45(2):131-6. 
9. Matsubara K. Computed Tomography Dosimetry: From Basic to State-of-the-art Techniques. Med Phys Inter J. 2017; 5(1): 61-6.

10. Način snemanja PET/CT. Onkološki inštitut Ljubljana, oddelek za nuklearno medicine. Verzija 1 / 20.03.2017.11. Huda W, Mettler FA. Volume CT Dose Index and DoseLength Product Displayed during CT: What Good Are They? Radiology. 2011; 258(1): 236-41.

12. Hara AK, Paden RG, Silva AC, Kujak JL, Lawder HJ, Pavlicek W. Iterative Reconstruction Technique for Reducing Body Radiation Dose at CT: Feasibility Study. Amer J Roentgenol. 2009; 193(3):764-70.

13. Fonti $R$, Conson $M$, Vecchio SD. PET/CT in radiation oncology. Amsterdam: Elsevier. 2019. Available from: https://www.sciencedirect.com/science/article/pii/ S009377541930079X. 